\title{
The effect of foliar application of urea, Mo and BA on nitrate metabolism in lettuce leaves in the spring and summer-autumn seasons
}

\author{
Renata Wojciechowska ${ }^{1}$, Iwona Kowalska ${ }^{2}$ \\ ${ }^{1}$ Department of Botany and Plant Physiology \\ ${ }^{2}$ Department of Soil Cultivation and Fertilisation in Horticulture \\ University of Agriculture in Krakow \\ 29 Listopada 54, 31-425 Kraków, Poland \\ e-mail: r.wojciechowska@ogr.ur.krakow.pl
}

\begin{abstract}
'Melodion' butter lettuce was grown on rockwool slabs in a film tunnel in the spring and summer-autumn seasons. The following experimental factors were investigated: foliar application with a solution of urea (1\%), Mo $\left(1 \mathrm{mg} \mathrm{dm}^{-3}\right)$ and benzyladenine $\left(5 \mathrm{mg} \mathrm{BA} \mathrm{dm}^{-3}\right)$ and light conditions in the film tunnel (films covering two parts of the tunnel differed in light permeability for PAR radiation). The nitrate metabolism was studied before application, three days after treatment and on the harvest day (seven days after application). Higher light intensity stimulated nitrate reductase activity, ammonium ions and soluble sugars, while fewer nitrates were observed in lettuce leaves. In the spring season, the least nitrate ions occurred as a consequence of urea + Mo nutrition, and when BA was added in the summer-autumn. Moreover, a positive effect on soluble sugar content was also observed when BA was used. In the spring, BA stimulated nitrate and nitrite reductase activities in the leaves of lettuce that had received less light.
\end{abstract}

Key words: light conditions, nitrate reductase, nitrite reductase, $\mathrm{NO}_{3}^{-}, \mathrm{NH}_{4}^{+}$, soluble sugars

\section{INTRODUCTION}

Leafy vegetables with a short vegetation period are able to accumulate high amounts of nitrates. For example, lettuce consumption may increase the $\mathrm{NO}_{3}^{-}$intake in human diets (Dapoigny et al. 2000). Nitrate content in fresh lettuce depends on the growing season due to varying climatic condition or production methods. According to scientific opinion (The EFSA Journal 2008), there is a sustained need for research into the factors that influence nitrate concentration in the edible parts of vegetables. It seems to be important to study various factors affecting nitrate metabolism in plants and to search for methods that may improve the biological quality of vegetables. It is well known that the level of nitrate in plants is closely connected with nitrate reductase (NR), the enzyme reducing $\mathrm{NO}_{3}^{-}$ ions. Light intensity via NR activity affects nitrate content in vegetables. Light is the main inducing factor that stimulates NR transcript levels and NR activity in post-transcriptional regulation (Yang and Midmore 2005). Nitrate reduction is also dependent on the molybdenum, the essential element that is an integral component of the nitrate reductase structure (Campbell 1999).

Nitrate and nitrite reductase activities in lettuce leaves are affected by growth regulators, mainly cytokinins (Rożek and Wojciechowska 1990). Recent studies showed that there is a close relationship between cytokinins and nitrates in plant growth via carbon metabolism regulation (Sakakibara et al. 2006). Cytokinin application may 
regulate plant growth as a reaction to changes in nitrogen supply.

Nitrogen fertilisation has been identified as a main factor influencing the concentration of nitrate in plants. It has been proven that a higher nitrogen dose, mainly in nitrate form, causes an $\mathrm{NO}_{3}$ - increase in vegetables because of an excess of nitrate uptake over its reduction (Chen et al. 2004). Some studies have indicated that foliar urea application may decrease the $\mathrm{NO}_{3}^{-}$level and improve the quality of the edible parts of vegetables, including lettuce leaves (Wojciechowska 2004).

The aim of the present study was to investigate the interaction of urea foliar application with molybdenum and benzyladenine (BA - synthetic cytokinin) on nitrate metabolism in lettuce grown under various light conditions. Special attention was paid to the nitrate reduction in leaves immediately before and after foliar nutrition.

\section{MATERIAL AND METHODS}

The experiment was carried out on 'Melodion' butter lettuce grown in a film tunnel in the spring and summer-autumn seasons of 2005. The plants were grown on rockwool slabs placed in channels using a drip fertigation system without recycling. Plants at a stage of four true leaves, produced in peat plugs $(5 \mathrm{~cm})$, were placed on $20 \times 7.5 \times 100$ $\mathrm{cm}$ Master (Grodan) rockwool slabs. Each slab contained three plants.

In both seasons, the plants were fed with the same nutrient solution containing $\left(\mathrm{mg} \mathrm{dm}^{-3}\right)$ : $\mathrm{N}\left(\right.$ as $\left.\mathrm{N}-\mathrm{NO}_{3}\right)-150, \mathrm{P}-50, \mathrm{~K}-200, \mathrm{Ca}$ $-150, \mathrm{Mg}-30$. Solution $\mathrm{pH}$ and $\mathrm{EC}$ were kept in the ranges of 6.0-6.2, and $1.8-2.0 \mathrm{mS} \mathrm{cm}^{-1}$, respectively.

Foliar nutrition of plants was the first experimental factor. The following combinations of treatments were tested: 1. control - without foliar nutrition, 2. foliar nutrition with solution containing urea $(1 \%)$ and molybdenum $(1 \mathrm{mg}$ $\left.\mathrm{dm}^{-3}\right)$, 3. foliar nutrition with solution containing urea (1\%), molybdenum $\left(1 \mathrm{mg} \mathrm{dm}^{-3}\right)$ and benzyladenine ( $5 \mathrm{mg} \mathrm{dm}^{-3} \mathrm{BA}$ ). Foliar nutrition was performed three times during each season, with 7-10 day intervals. The fertiliser solution was distributed using a manual sprayer until the leaves were completely wet. The first foliar nutrition was performed one week after the placement of plants in slabs, whereas the last one took place eight days before harvest. There were 27 plants $(9$ plants $\times$ 3 replicates) in each combination.

Lettuce was grown in a film tunnel divided into two parts (A and B). Tunnel A was covered with
Ginegar film, whereas tunnel B with Gemme 4S film. The films differed in light permeability for PAR radiation: Ginegar transmitted light with an intensity of $200-220 \mu \mathrm{mol} \mathrm{m} \mathrm{m}^{-2} \mathrm{~s}^{-1}$ on cloudy days and $650-750 \mu \mathrm{mol} \mathrm{m} \mathrm{m}^{-2} \mathrm{~s}^{-1}$ on sunny days, whereas Gemme $4 \mathrm{~S}$ transmitted about $30 \%$ more radiation, 300-320 and 950-1000 $\mu \mathrm{mol} \mathrm{m}^{-2} \mathrm{~s}^{-1}$, respectively. The light intensity was measured for several days during both growing cycles. The difference in the radiation intensity in the range of PAR was the second experimental factor.

The time of analysis was the third experimental factor. Chemical analyses were conducted on three fixed dates: before the last foliar application (date I: 11 April and 11 October), three days after (date II: 14 April and 14 October) and on harvest day (date III: 18 April and 18 October). 15 plants were randomly chosen and marked from each combination. Two leaves were taken from each plant for analysis, always at 8.00 in the morning. The leaves were at a stage just before the end of growth (not internal in the head and not external and having grown old). The following chemical analyses were performed: activity of nitrate reductase and nitrite reductase using the method published by Buczek (1984), nitrate and ammonium ion content using the potentiometric method using a UNICAM-9460 ionmeter, as well as soluble sugars using the anthrone method.

The results were subjected to an analysis of variance, independent for each growing season. Differences between the means were tested using the Newman-Keuls test at a significance level of $\alpha=0.05$.

\section{RESULTS AND DISCUSSION}

A significant influence of light intensity on nitrate metabolism was discovered (Tabs 1 and 2). The results showed a similar trend in both growing seasons and confirmed the relationship between light intensity, NR activity and nitrate level in the plants. When plants received more light (Part B of the film tunnel as compared with A), we observed higher nitrate reductase activity, more ammonium ions and soluble sugars as well as fewer nitrates in lettuce leaves. The nitrate concentration decreased by about $30 \%$ in the leaves that had received $30 \%$ more light. Similarly, Dapoigny et al. (2000) showed an increase in nitrates in shaded lettuce grown in a plastic tunnel. In another study with lettuce grown in low tunnels or shaded a week before harvest with the reducing of film permeability for PAR, a decrease of nitrate reductase activity and an increase 
Table 1. The effect of foliar nutrition, light intensity and the term of study on nitrate reductase activity (NR), nitrite reductase activity $(\mathrm{NiR})$, nitrate, ammonium and soluble sugar content in lettuce leaves in the spring growing cycle

\begin{tabular}{|c|c|c|c|c|c|}
\hline Treatment & $\begin{array}{c}\mathrm{NR} \\
\left(\mu \mathrm{mol} \mathrm{NO}{ }_{2}^{-} \mathrm{g}^{-1} \text { f.m. } \mathrm{h}^{-1}\right)\end{array}$ & $\begin{array}{c}\mathrm{NiR} \\
\left(\mu \mathrm{mol} \mathrm{NO}{ }^{-} \mathrm{g}^{-1} \text { f.m. } \mathrm{h}^{-1}\right)\end{array}$ & $\begin{array}{c}\mathrm{NO}_{3}^{-} \\
\left(\mu \mathrm{mol} \mathrm{g}{ }^{-1} \text { f.m.) }\right.\end{array}$ & $\begin{array}{c}\mathrm{NH}_{4}^{+} \\
\left(\mu \mathrm{mol} \mathrm{g}{ }^{-1} \text { f.m. }\right)\end{array}$ & $\begin{array}{l}\text { Soluble sugars } \\
\text { (mg g-1 f.m.) }\end{array}$ \\
\hline \multicolumn{6}{|l|}{ Foliar nutrition } \\
\hline Control & $3.99 \mathrm{a}$ & $4.22 \mathrm{a}$ & $12.95 \mathrm{~b}$ & $20.36 b$ & $20.83 \mathrm{a}$ \\
\hline Urea + Mo & $4.03 \mathrm{a}$ & $4.10 \mathrm{a}$ & $12.11 \mathrm{a}$ & $19.40 \mathrm{a}$ & $22.31 \mathrm{~b}$ \\
\hline $\mathrm{Urea}+\mathrm{Mo}+\mathrm{BA}$ & $4.15 \mathrm{a}$ & $4.32 \mathrm{a}$ & $13.11 \mathrm{~b}$ & $20.08 \mathrm{~b}$ & $22.08 \mathrm{~b}$ \\
\hline \multicolumn{6}{|l|}{ Tunnel } \\
\hline A & $3.93 \mathrm{a}$ & $4.22 \mathrm{a}$ & $14.94 \mathrm{~b}$ & $18.92 \mathrm{a}$ & $21.49 \mathrm{a}$ \\
\hline $\mathrm{B}^{*}$ & $4.18 \mathrm{~b}$ & $4.21 \mathrm{a}$ & $10.51 \mathrm{a}$ & $20.98 \mathrm{~b}$ & $22.00 \mathrm{~b}$ \\
\hline \multicolumn{6}{|l|}{ Term } \\
\hline I & $6.11 \mathrm{c}$ & $4.41 \mathrm{~b}$ & $13.47 \mathrm{~b}$ & $17.97 \mathrm{a}$ & $19.08 \mathrm{a}$ \\
\hline II & $3.11 \mathrm{~b}$ & $5.11 \mathrm{c}$ & $14.36 \mathrm{c}$ & $19.46 \mathrm{~b}$ & $22.98 \mathrm{~b}$ \\
\hline III & $2.93 \mathrm{a}$ & $3.13 \mathrm{a}$ & $10.06 \mathrm{a}$ & $22.42 \mathrm{c}$ & $23.17 \mathrm{~b}$ \\
\hline
\end{tabular}

$* 30 \%$ more of PAR than in tunnel A; f.m. - fresh matter; values marked in columns with the same letter do not differ significantly for $\alpha=0.05$

Table 2. The effect of foliar nutrition, light intensity and the term of study on nitrate reductase activity (NR), nitrite reductase activity (NiR), nitrate, ammonium and soluble sugar content in lettuce leaves in the summer-autumn growing cycle

\begin{tabular}{|c|c|c|c|c|c|}
\hline Treatment & $\begin{array}{c}\mathrm{NR} \\
\left(\mu \mathrm{mol} \mathrm{NO}{ }^{-} \mathrm{g}^{-1} \text { f.m. } \mathrm{h}^{-1}\right)\end{array}$ & $\begin{array}{c}\mathrm{NiR} \\
\left(\mu \mathrm{mol} \mathrm{NO}{ }^{-} \mathrm{g}^{-1} \text { f.m. } \mathrm{h}^{-1}\right)\end{array}$ & $\begin{array}{c}\mathrm{NO}_{3}^{-} \\
\left(\mu \mathrm{mol} \mathrm{g}{ }^{-1} \text { f.m. }\right) \\
\end{array}$ & $\begin{array}{c}\mathrm{NH}_{4}^{+} \\
\left(\mu \mathrm{mol} \mathrm{g}{ }^{-1} \text { f.m. }\right) \\
\end{array}$ & $\begin{array}{c}\text { Soluble sugars } \\
\text { (mg g-1 f.m.) }\end{array}$ \\
\hline \multicolumn{6}{|l|}{ Foliar nutrition } \\
\hline Control & $4.54 \mathrm{a}$ & $3.74 \mathrm{a}$ & $31.10 \mathrm{~b}$ & $23.78 \mathrm{~b}$ & $6.78 \mathrm{~b}$ \\
\hline Urea + Mo & $4.51 \mathrm{a}$ & $3.68 \mathrm{a}$ & $31.01 \mathrm{~b}$ & $24.23 \mathrm{~b}$ & $6.43 \mathrm{a}$ \\
\hline $\mathrm{Urea}+\mathrm{Mo}+\mathrm{BA}$ & $4.49 \mathrm{a}$ & $3.62 \mathrm{a}$ & $24.20 \mathrm{a}$ & $21.71 \mathrm{a}$ & $8.77 \mathrm{c}$ \\
\hline \multicolumn{6}{|l|}{ Tunnel } \\
\hline A & $4.36 \mathrm{a}$ & $3.65 \mathrm{a}$ & $33.34 \mathrm{~b}$ & $21.64 \mathrm{a}$ & $6.85 \mathrm{a}$ \\
\hline $\mathrm{B}^{*}$ & $4.67 \mathrm{~b}$ & $3.71 \mathrm{a}$ & $24.19 \mathrm{a}$ & $24.83 \mathrm{~b}$ & $7.80 \mathrm{~b}$ \\
\hline \multicolumn{6}{|l|}{ Term } \\
\hline I & $5.63 \mathrm{~b}$ & $2.15 \mathrm{a}$ & $28.38 \mathrm{~b}$ & $30.66 \mathrm{c}$ & $7.79 \mathrm{~b}$ \\
\hline II & $3.82 \mathrm{a}$ & $4.54 \mathrm{c}$ & $26.62 \mathrm{a}$ & $24.90 \mathrm{~b}$ & $6.51 \mathrm{a}$ \\
\hline III & $3.10 \mathrm{a}$ & $4.35 \mathrm{~b}$ & $31.30 \mathrm{c}$ & $14.15 \mathrm{a}$ & $7.67 \mathrm{~b}$ \\
\hline
\end{tabular}

*Explanations: see Table 1

of nitrates in leaves were shown (Wojciechowska and Siwek 2007).

According to results presented in Tables 1 and 2, the influence of foliar nutrition on nitrate and nitrite reductase activity was non-significant. The effect of the solutions used in foliar application on other parameters was not clear and strongly depended on the growing season. In spring, the lowest level of nitrates in the tested lettuce leaves was found after urea + Mo application, whereas this occurred when a benzyladenine was used in autumn. Moreover, a positive effect on soluble sugar content was also observed when BA was added. In comparison to the control plants, this stimulation occurred in plants treated with urea + Mo + BA and grown in both parts of the film greenhouse (Tab. 4). Benzyladenine application had a very positive effect on sugar accumulation in lettuce leaves in autumn, when the days had become shorter and shorter. During spring growing, BA stimulated nitrate and nitrite reductase activity in plants which received less light (Tab. 3, tunnel A). This BA action could be explained by an interaction between cytokinin and nitrogen regulatory systems. It has been shown that cytokinins and nitrates may regulate photosynthetic capacity and plant growth via some sucrose content (Sakakibara et al. 2006).

However, in comparison with the control plants (without foliar nutrition), the urea + Mo solution affected the increase of soluble sugars and decrease of nitrates in lettuce leaves both in the spring and 
Table 3. The effect of foliar nutrition and light intensity irrespective of the term of study on nitrate reductase activity (NR), nitrite reductase activity (NiR), nitrate, ammonium and soluble sugar content in lettuce leaves in the spring growing cycle

\begin{tabular}{lccccc}
\hline Treatment & $\begin{array}{c}\mathrm{NR} \\
\left(\mu \mathrm{mol} \mathrm{NO}{ }^{-} \mathrm{g}^{-1} \mathrm{f} . \mathrm{m}^{-1}\right)\end{array}$ & $\begin{array}{c}\mathrm{NiR} \\
\left(\mu \mathrm{mol} \mathrm{NO}{ }^{-} \mathrm{g}^{-1} \mathrm{f} . \mathrm{m} . \mathrm{h}^{-1}\right)\end{array}$ & $\begin{array}{c}\mathrm{NO}_{3}^{-} \\
\left(\mu \mathrm{mol} \mathrm{g}^{-1} \mathrm{f} . \mathrm{m} .\right)\end{array}$ & $\begin{array}{c}\mathrm{NH}_{4}^{+} \\
\left(\mu \mathrm{mol} \mathrm{g}^{-1} \mathrm{f} . \mathrm{m} .\right)\end{array}$ & $\begin{array}{c}\text { Soluble sugars } \\
\left(\mathrm{mg} \mathrm{g}^{-1} \mathrm{f} . \mathrm{m}\right)\end{array}$ \\
\hline Tunnel A & & & & & \\
Control & $3.82 \mathrm{a}$ & $4.22 \mathrm{~b}$ & $15.55 \mathrm{c}$ & $19.66 \mathrm{~b}$ & $19.89 \mathrm{a}$ \\
Urea + Mo & $3.79 \mathrm{a}$ & $3.95 \mathrm{a}$ & $13.81 \mathrm{~b}$ & $17.71 \mathrm{a}$ & $22.47 \mathrm{c}$ \\
Urea + Mo + BA & $4.17 \mathrm{~b}$ & $4.48 \mathrm{c}$ & $15.47 \mathrm{c}$ & $19.39 \mathrm{ab}$ & $22.10 \mathrm{bc}$ \\
\hline Tunnel B & & & & & \\
Control & $4.15 \mathrm{~b}$ & $4.22 \mathrm{~b}$ & $10.35 \mathrm{a}$ & $21.07 \mathrm{~b}$ & $21.78 \mathrm{~b}$ \\
Urea + Mo & $4.26 \mathrm{~b}$ & $4.26 \mathrm{~b}$ & $10.42 \mathrm{a}$ & $21.10 \mathrm{~b}$ & $22.15 \mathrm{bc}$ \\
Urea + Mo + BA & $4.12 \mathrm{~b}$ & $4.16 \mathrm{~b}$ & $10.75 \mathrm{a}$ & $20.77 \mathrm{~b}$ & $22.07 \mathrm{bc}$ \\
\hline
\end{tabular}

*Explanations: see Table 1

Table 4. The effect of foliar nutrition and light intensity irrespective of the term of study on nitrate reductase activity (NR), nitrite reductase activity (NiR), nitrate, ammonium and soluble sugar content in lettuce leaves in the summerautumn growing cycle

\begin{tabular}{|c|c|c|c|c|c|}
\hline Treatment & $\begin{array}{c}\mathrm{NR} \\
\left(\mu \mathrm{mol} \mathrm{NO}{ }^{-} \mathrm{g}^{-1} \text { f.m. } \mathrm{h}^{-1}\right)\end{array}$ & $\begin{array}{c}\mathrm{NiR} \\
\left(\mu \mathrm{mol} \mathrm{NO}{ }^{-} \mathrm{g}^{-1} \text { f.m. } \mathrm{h}^{-1}\right)\end{array}$ & $\begin{array}{c}\mathrm{NO}_{3}^{-} \\
\left(\mu \mathrm{mol} \mathrm{g}{ }^{-1} \text { f.m. }\right)\end{array}$ & $\begin{array}{c}\mathrm{NH}_{4}^{+} \\
(\mu \mathrm{mol} \mathrm{g} \\
\end{array}$ & $\begin{array}{l}\text { Soluble sugars } \\
\text { (mg g } \mathrm{m}^{-1} \text { f.m.) }\end{array}$ \\
\hline \multicolumn{6}{|l|}{ Tunnel A } \\
\hline Control & $4.41 \mathrm{ab}$ & $3.69 \mathrm{~b}$ & $37.89 \mathrm{e}$ & $22.85 \mathrm{~b}$ & $5.82 \mathrm{a}$ \\
\hline $\mathrm{Urea}+\mathrm{Mo}$ & $4.26 \mathrm{a}$ & $3.53 \mathrm{a}$ & $33.85 \mathrm{~d}$ & $22.88 \mathrm{~b}$ & $6.39 \mathrm{~b}$ \\
\hline $\mathrm{Urea}+\mathrm{Mo}+\mathrm{BA}$ & $4.41 \mathrm{ab}$ & $3.72 \mathrm{~b}$ & $28.30 \mathrm{c}$ & $19.20 \mathrm{a}$ & $8.35 \mathrm{~d}$ \\
\hline \multicolumn{6}{|l|}{ Tunnel B* } \\
\hline Control & $4.68 \mathrm{c}$ & $3.79 \mathrm{~b}$ & $24.31 \mathrm{~b}$ & $24.71 b c$ & $7.75 \mathrm{c}$ \\
\hline Urea + Mo & $4.75 \mathrm{bc}$ & $3.82 \mathrm{~b}$ & $28.18 \mathrm{c}$ & $25.57 \mathrm{c}$ & $6.47 \mathrm{~b}$ \\
\hline $\mathrm{Urea}+\mathrm{Mo}+\mathrm{BA}$ & $4.58 \mathrm{c}$ & $3.51 \mathrm{a}$ & $20.09 \mathrm{a}$ & $24.22 \mathrm{bc}$ & $9.19 \mathrm{e}$ \\
\hline
\end{tabular}

*Explanations: see Table 1

autumn in tunnel A (Tabs 3 and 4). This relationship suggests that the demand for nitrogen in poor light conditions can be supplemented by foliar application with a reduced form of N. Similarly, we noted an advantageous effect of foliar urea nutrition on quality yield of lettuce both in greenhouse (Kowalska 1998) or field growing (Wojciechowska 2004) in our previous studies.

For a better explanation of the above relationship, the study was conducted before and after three and seven days from the last foliar application (Tabs 1 and 2, see: terms). In both growing seasons, the highest nitrate reductase activity in lettuce leaves was found before foliar nutrition. After that NR activity decreased, and reached the lowest level at harvest time. In the case of nitrite reductase, a significant increase was observed on the third day after foliar application, followed by a decrease on the seventh day. Similarly, changes of both enzyme activities were found in previous investigations with 'Sprinter' lettuce in field growing after urea foliar nutrition (Wojciechowska 2004). The results suggest that there is a certain regularity in nitrate metabolism after foliar application of urea in leaves of this species.

Dapoigny et al. (2000) reported that nitrate content in lettuce increased at the end of the crop cycle in autumn as compared to the spring due to the lower light intensity. Our results confirmed this trend. It is worth mentioning that nitrate concentration between terms II and III, i.e. during the four days before the harvest, showed differing changes depending on the growing season (Tabs 1 and 2). In the spring, $\mathrm{NO}_{3}^{-}$content in leaves significantly decreased, but in autumn, it increased. That was due to the day length influence in the day-and-night cycle on nitrate bioaccumulation. Similarly, Kozik (2006) observed a significant correlation between solar radiation during the growing period and nitrate content in lettuce.

Ammonium ion content in lettuce leaves did not increase after urea application. This could be explained by an active incorporation of the reduced $\mathrm{N}$ form to organic plant compounds. The evaluation 
of the effect of foliar application with urea, Mo and BA on lettuce yield and its quality was presented in a previous study (Kowalska and Sady 2010).

\section{CONCLUSIONS}

1. Following foliar nutrition, nitrate reductase activity in lettuce leaves gradually decreased, but in the case of nitrite reductase a significant increase followed by a decrease was observed.

2. In the spring growing cycle, BA stimulated nitrate and nitrite reduction in the leaves of lettuce grown in a tunnel with less light intensity.

3. In the summer-autumn growing season, when lettuce leaves accumulated more nitrates as compared to the spring cycle, a foliar treatment with urea $(1 \%)+$ Mo $\left(1 \mathrm{mg} \mathrm{dm}^{-3}\right)+\mathrm{BA}(5 \mathrm{mg}$ $\left.\mathrm{dm}^{-3}\right)$ simultaneously decreased nitrates and increased soluble sugars in leaves.

\section{REFERENCES}

BuczeK J., 1984. The occurrence of nitrate reductase inactivating factor in extracts of Spirodela polyrrhiza. Acta Soc. Bot. Pol. 53: 411-417.

CAmpBell W.H., 1999. Nitrate reductase structure, function and regulation: Bridging the gap between biochemistry and physiology. Ann. Rev. Plant Physiol. Plant Mol. Biol. 50: 277-303.

Chen B.M., Wang Z.H., Li S.X., Wang G.X., Song H.X., WANG X.N., 2004. Effects of nitrate supply on plant growth, nitrate accumulation, metabolic nitrate concentration and nitrate reductase activity in three leafy vegetables. Plant Sci. 167: 635-643.

Dapoigny L., de Tourdonnet S., Roger-Estrade J., Jeufroy M.H., Fleury A., 2000. Effect of nitrogen nutrition on growth and nitrate accumulation in lettuce (Lactuca sativa L.), under various conditions of radiation and temperature. Agronomie 20: 843-855.

KowALSKA I., 1998. Zawartość azotanów w sałacie szklarniowej w zależności od sposobu nawożenia azotem. Mat. Konf. Nauk. „Efektywność stosowania nawozów w uprawach ogrodniczych", 8-9 czerwiec, Lublin: 127-130.

KowalsKa I., SADY W., 2010. Effect of poliethylene film covering the greenhouse, nitrogen fertilizer form and foliar nutrition on the yield and quality of lettuce. Folia Hort. 22(1): 37-44.

KozIK E., 2006. Effect of harvest term and nitrogen and potassium fertilization on the content of nitrates in greenhouse lettuce. Acta Agrophysica 7(3): 633-642.

Rożex S., Wojciechowska R., 1990. Effect of light and growth regulators on the circadian rhytmicity of nitrate reductase and nitrite reductase activities in greenhouse lettuce leaves. Folia Hort. 2(1): 53-64.
SaKakibara H., TAKei K., Hirose N., 2006. Interactions between nitrogen and cytokinin in the regulation of metabolism and development. Trends in Plant Science 11(9): 440-448.

The EFSA Journal, 2008. Opinion of the Scientific Panel on Contaminant in the Food chain on a request from the European Commission to perform a scientific risk assessment on nitrate in vegetables 689: 1-79.

Wojciechowska R., 2004. Some aspects of nitrate metabolism in vegetables with special reference to butterhead lettuce 'Sprinter'. Zesz. Nauk. AR w Krakowie. Ser. Rozprawy: 297.

Wojciechowska R., Siwek P., 2007. The effect of the kind of polyethylene film used for cover of low tunnels and plant shading before harvest on nitrate metabolism in butterhead lettuce. Folia Hort. 19(2): 99-107.

YANG Z., Midmore D.J., 2005. A model for the circadian oscillation in expression and activity of nitrate reductase in higher plants. Ann. Bot. 96: 1019-1026.

WPŁYW APLIKACJI DOLISTNEJ

MOCZNIKIEM, Mo I BA NA METABOLIZM

AZOTANÓW W LIŚCIACH SAŁATY W UPRAWIE WIOSENNEJ I LETNIO -JESIENNEJ

Streszczenie: Obiektem badań była sałata masłowa 'Melodion' uprawiana na matach z wełny mineralnej w tunelu foliowym w sezonie wiosennym i letnio-jesiennym. Czynnikami doświadczenia była aplikacja dolistna mocznikiem (1\%), molibdenem (1 $\mathrm{mg} \mathrm{Mo} \mathrm{dm}^{-3}$ ) i benzyloadeniną (5 mg BA $\mathrm{dm}^{-3}$ ) oraz zróżnicowane natężenie napromienienia w zakresie PAR, docierające do roślin w dwóch częściach tunelu foliowego. Metabolizm azotanów badano tuż przed zabiegiem, trzy dni po i w dniu zbioru plonu ( 7 dni od zabiegu). W części tunelu, w której do roślin docierało więcej światła liście sałaty charakteryzowały się wyższą aktywnością reduktazy azotanowej, większą zawartością jonów amonowych, wolnych aminokwasów, cukrów rozpuszczalnych oraz niższym poziomem azotanów. W uprawie wiosennej zawartość azotanów była najmniejsza w liściach roślin dokarmianych dolistnie mocznikiem z Mo, natomiast $\mathrm{w}$ jesiennej - po dodaniu do mieszaniny benzyloadeniny. W tym ostatnim przypadku zaobserwowano także bardzo wyraźną stymulację syntezy cukrowców. Benzyloadenina wpływała na zwiększenie aktywności reduktazy azotanowej i azotynowej wiosną $w$ liściach sałaty rosnącej w gorszych warunkach świetlnych.

Received October 15, 2010; accepted December 7, 2011 